\title{
COMPLEMENT AND ITS COMPONENT FRACTIONS IN CEREBROSPINAL FLUID IN INFLAMMATORY CEREBROSPINAL DISEASES
}

\author{
By SOPHIE SPICER, EMANUEL APPELBAUM, AND DAVID D. RUTSTEIN
}

(From the Bureau of Laboratories of the Department of Health of the City of New York)

(Received for publication October 9, 1948)

It is generally agreed that normal spinal fluid is entirely devoid of complement, but the reports of its presence in the spinal fluid in cerebrospinal diseases are contradictory. Complement was found in the spinal fluid of all cases of meningococcus meningitis by Ward and Fothergill (1), but was reported to be absent in the same diseases by others $(2-4)$. Ward et al. $(1,5)$ found complement to be absent in the spinal fluid of cases of influenzal meningitis. Hauptmann (6) reported that complement may be found in the spinal fluid of tuberculous meningitis, but not in meningitis of other types. An early report (7) indicated that complement was absent from spinal fluids in various pathological conditions of the central nervous system, including cases with signs of meningitis.

Present evidence indicates that complement activity results from the action of at least four components, more or less loosely combined, and present in different concentrations (8-10). When one or more of these components are missing, there is an absence of complement activity. Since the component in least concentration determines the titer of complement activity (8-10), evidence of such activity will be found when that component is present in minute amounts, and negative results will be obtained when it is entirely absent, although the other three components may be present in considerable quantities. This makes it possible to titrate each of the four components of complement independently by the addition of the other three components in excess. In accordance with the terminology adopted by Pillemer and Ecker (11) and Bier et al. (9) for complement and its components, whole complement as demonstrated by hemolytic activity is designated as $C^{\prime}$ and the four components are designated as $C^{\prime} 1, C^{\prime} 2, C^{\prime} 3$ and $C^{\prime} 4$. This evidence has been collected from studies of complement activity in blood serum (810). There are no reports of similar studies in human cerebrospinal fluid.

\section{MATERIALS AND METHODS}

Definition of reagents. A reagent used for the titration of a given component of complement does not contain the component to be titrated, but contains the three other components. Thus, reagent 1 (RI) contains $\mathrm{C}^{\prime} 2$, $C^{\prime} 3$, and $C^{\prime} 4$, but not $C^{\prime} 1$, and is used for the titration of $C^{\prime} 1$. Reagent 2 (R2) does not contain $C^{\prime} 2$, but $C^{\prime} 1$, $\mathrm{C}^{\prime} 3$ and $\mathrm{C}^{\prime} 4$ and is used for the titration of $\mathrm{C}^{\prime} 2$. Likewise $\mathrm{R} 3$ has all the components but $\mathrm{C}^{\prime} 3$, and $\mathrm{R} 4$ all the components but $\mathrm{C}^{\prime} 4$, being used for the titration of $C^{\prime} 3$ and $C^{\prime} 4$ respectively. Since all four components are required to produce hemolysis of sensitized red blood cells, each of the reagents by itself does not produce hemolysis.

Complement for the preparation of reagents was secured from guinea pigs, which were stunned by a blow at the base of the skull and were bled from the throat into sterile Petri dishes. The blood was left at room temperature protected from light for 30 minutes, and then placed in an icebox overnight. The serum was then drawn off, centrifuged and used immediately. No stored guinea pig serum was used in the preparation of reagents.

Preparation of reagents. With the exception of R3, the methods of preparation of reagents were in general those of Heidelberger and his coworkers, with one major exception. The preparation of zymosan, used by these workers for the inactivation of the third component, is tedious and time consuming. Powdered zymin, which was used instead, is easy to prepare, yields an excellent reagent and lasts a long time. There were also minor variations in the preparation of the other reagents.

In the separation of complement into R1 (endpiece) and R2 (midpiece) by $\mathrm{KH}_{2} \mathrm{PO}_{4}$ or $\mathrm{CO}_{2}$ as carried out in the laboratories of Heidelberger (9) and Ecker (10), the same preparation supplies both the R1 (supernatant fluid) and R2 (precipitate). This routine was varied since a more effective $\mathrm{R} 1$ was obtained by one method $\left(\mathrm{KH}_{2} \mathrm{PO}_{4}\right)$ and a better $\mathrm{R} 2$ by the other method $\left(\mathrm{CO}_{2}\right)$.

Preparation of $R 1$. To 9 volumes of chilled $M / 200$ $\mathrm{KH}_{2} \mathrm{PO}$, solution 1 volume of chilled guinea pig serum was added slowly with constant mixing. After $20 \mathrm{~min}-$ utes at $0^{\circ} \mathrm{C}$. the mixture was rapidly centrifuged in an angle centrifuge at a speed of 4000 RPM. The supernatant fluid was decanted, made isotonic with $17 \% \mathrm{NaCl}$ and neutralized with $0.1 \mathrm{~N} \mathrm{NaHCO}$. Five ml. amounts of the reagent were measured out into small bottles, tightly plugged, immediately placed in the freezing compartment of the refrigerator and kept in the frozen state until used. 
Preparation of $R 2$. A small flask containing distilled water was placed in a beaker full of cracked ice and pure $\mathrm{CO}_{2}$ gas was allowed to bubble through the water for 30 minutes under slight pressure. One $\mathrm{ml}$. of guinea pig serum was added to $9 \mathrm{ml}$. of the $\mathrm{CO}_{2}$ saturated water and $\mathrm{CO}_{2}$ gas was again passed through the mixture for 20 minutes, keeping the mixture cold. The precipitate formed after 20 minutes' saturation of the serum with $\mathrm{CO}_{2}$ was rapidly centrifuged in an angle centrifuge at a speed of 4000 RPM, the supernatant fluid was poured off and the precipitate well drained of the fluid by holding a piece of absorbent cotton to the mouth of the inverted tube. The precipitate was then redissolved in $5 \mathrm{ml}$. of buffered saline solution. This constitutes R2 and was also stored in the frozen state.

Preparation of R3. Powdered zymin was used in the inactivation of the third component of guinea pig complement. It was prepared as follows: Approximately 5 grams of fresh yeast (Fleischmann's) were placed into a $100 \mathrm{ml}$. bottle containing $60 \mathrm{ml}$. absolute alcohol and the mixture was shaken well for 10 minutes. The suspension was then allowed to stand until the large particles settled. Only the very fine particles were collected by careful decanting. It was occasionally necessary to repeat this process to get rid of the coarser particles. The fine suspension was then centrifuged in $50 \mathrm{ml}$. tubes. The

TABLE I

Results of titration of complement components in cerebrospinal fluids from cases of meningitis compared with laboratory findings

Pneumococcus meningitis

\begin{tabular}{|c|c|c|c|c|c|c|c|c|c|c|c|}
\hline \multirow{2}{*}{$\begin{array}{l}\text { Case } \\
\text { No. }\end{array}$} & \multirow{2}{*}{$\begin{array}{c}\text { Date of } \\
\text { onset of } \\
\text { meningeal } \\
\text { symptoms }\end{array}$} & \multirow{2}{*}{$\begin{array}{c}\text { Date } \\
\text { 8pinal } \\
\text { fluid was } \\
\text { taken }\end{array}$} & \multicolumn{5}{|c|}{ Complement and its components* } & \multicolumn{4}{|c|}{ Laboratory findings $†$} \\
\hline & & & $\mathbf{C}^{\prime}$ & $C^{\prime} 1$ & $C^{\prime} 2$ & $C^{\prime} 3$ & $C^{\prime} 4$ & $\begin{array}{c}\text { Total } \\
\text { protein } \\
\text { in } \mathrm{mgm} . \\
\text { per } 100 \mathrm{ml} .\end{array}$ & $\begin{array}{c}\text { Sugar } \\
\text { in mgm. } \\
\text { per } 100 \mathrm{ml} \text {. }\end{array}$ & $\begin{array}{c}\text { Cell } \\
\text { count }\end{array}$ & $\begin{array}{c}\text { Micro- } \\
\text { organisms }\end{array}$ \\
\hline $\begin{array}{l}1 \\
2 \\
3 \\
4 \\
5 \\
6 \\
7 \\
8 \\
9\end{array}$ & $\begin{array}{c}10 / 14 \\
12 / 18 \\
12 / 14 \\
2 / 4 \\
3 / 26 \\
- \\
3 / 16 \\
3 / 3 \\
-\end{array}$ & $\begin{array}{c}11 / 16 \\
12 / 19 \\
12 / 16 \\
2 / 6 \\
4 / 4 \\
3 / 26 \\
3 / 18 \\
4 / 3 \\
4 / 16\end{array}$ & $\begin{array}{l}- \\
- \\
- \\
- \\
- \\
- \\
+ \\
+4\end{array}$ & & $\begin{array}{l}- \\
- \\
- \\
- \\
- \\
- \\
+ \\
+t\end{array}$ & - & - & $\begin{array}{r}38 \\
330 \\
109 \\
64 \\
86 \\
123 \\
225 \\
165 \\
246\end{array}$ & $\begin{array}{r}53 \\
0 \\
25 \\
24 \\
66 \\
10 \\
25 \\
16 \\
74\end{array}$ & $\begin{array}{l}\text { M.I. } \\
\text { L.I. } \\
\text { L.I. } \\
\text { L.I. } \\
\text { L.I. } \\
\text { L.I. } \\
\text { L.I. } \\
\text { L.I. } \\
\text { L.I. }\end{array}$ & $\begin{array}{l}\text { Neg. } \\
\text { Pos. } \\
\text { Pos. } \\
\text { Pos. } \\
\text { Pos. } \\
\text { Neg. } \\
\text { Pos. } \\
\text { Pos. } \\
\text { Neg. }\end{array}$ \\
\hline
\end{tabular}

Meningococcus meningitis

\begin{tabular}{|c|c|c|c|c|c|c|c|c|c|c|c|}
\hline $\begin{array}{l}10 \\
11 \\
12 \\
13 \\
14 \\
15 \\
16 \\
17\end{array}$ & $\begin{array}{l}1 / 6 \\
\overline{1} / 18 \\
1 / 18 \\
2 / 24 \\
5 / 29 \\
6 / 3 \\
7 / 15\end{array}$ & $\begin{array}{l}1 / 11 \\
1 / 28 \\
2 / 1 \\
2 / 1 \\
2 / 26 \\
6 / 1 \\
6 / 5 \\
7 / 15\end{array}$ & $\begin{array}{l} \pm \\
- \\
- \\
+ \\
- \\
+\end{array}$ & & $\begin{array}{l} \pm \\
- \\
- \\
+ \\
- \\
+ \\
+\end{array}$ & -+ & $\begin{array}{l}++++ \\
++++ \\
++++ \\
++++ \\
++++ \\
++++ \\
++++ \\
++++\end{array}$ & $\begin{array}{r}297 \\
83 \\
65 \\
210 \\
465 \\
82 \\
39 \\
290\end{array}$ & $\begin{array}{r}0 \\
0 \\
56 \\
57 \\
10 \\
79 \\
69 \\
12\end{array}$ & $\begin{array}{l}\text { L.I. } \\
\text { L.I. } \\
\text { L.I. } \\
\text { L.I. } \\
\text { L.I. } \\
\text { L.I. } \\
\text { L.I. } \\
\text { L.I. }\end{array}$ & $\begin{array}{l}\text { Pos. } \\
\text { Pos. } \\
\text { Neg. } \\
\text { Neg. } \\
\text { Pos. } \\
\text { Neg. } \\
\text { Neg. } \\
\text { Pos. }\end{array}$ \\
\hline
\end{tabular}

Tuberculous meningitis and other forms of meningitis

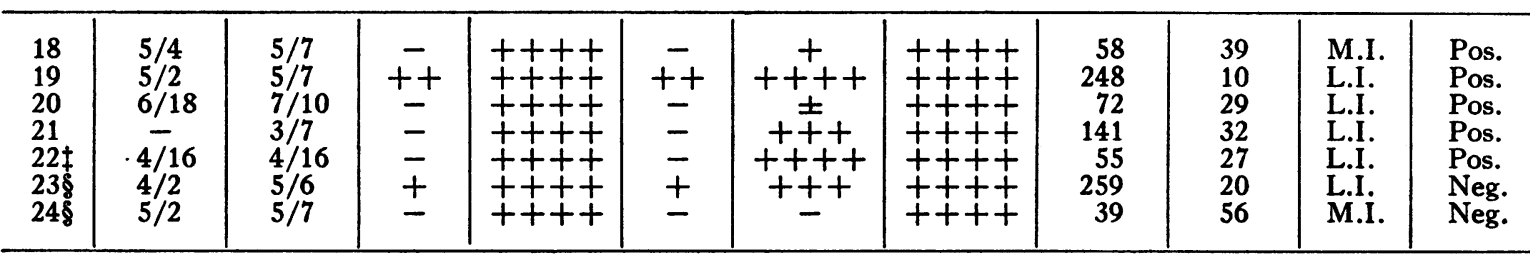

* Relative degree of hemolysis as determined by comparison with color standards

$$
\begin{array}{ll}
++++ & =100 \% \text { hemolysis } \\
+++ & =70 \% \text { to } 95 \% \text { hemolysis } \\
+ & =35 \% \text { to } 65 \% \text { hemolysis } \\
+ & =10 \% \text { to } 30 \% \text { hemolysis } \\
+ & =5 \% \text { hemolysis } \\
\pm & =\text { No hemolysis }
\end{array}
$$

$\ddagger$ Hem. strept. meningitis

Influenzal meningitis $\dagger$ Normal spinal fluid

Total protein 0-30 mgm. per $100 \mathrm{ml}$.

Sugar $\quad 40-60 \mathrm{mgm}$. per $100 \mathrm{ml}$.

Cell count 0-10 per cmm

M.I. = Moderate increase

31-199 cells per cmm

L.I. = Large increase

200 cells or more 
alcohol was decanted and an equivalent amount of ether added. The suspension was shaken well and centrifuged at $800 \mathrm{RPM}$ with the lid of the centrifuge open. The ether was then decanted and the sediment spread about the inner surface of the tube with a glass rod to facilitate drying. The zymin thus prepared was a fine impalpable white powder, weighing approximately 0.2 gram. If kept in a dry state, preferably over $\mathrm{CaCl}_{2}$, it will last for at least three to four months. The number of bottles to be used depends on the amount of zymin desired.

To prepare R3, one gram of powdered zymin was added to $30 \mathrm{ml}$. of buffered saline, mixed well and placed in a boiling water bath for 30 minutes, being stirred occasionally. It was then removed from the water bath, distributed equally into three $15 \mathrm{ml}$. centrifuge tubes and centrifuged for five minutes at $1500 \mathrm{RPM}$. The supernatant fluid was decanted as completely as possible. Each tube then contained the boiled zymin in a volume of about $0.5 \mathrm{ml}$. One $\mathrm{ml}$. of guinea pig serum was added to each tube, stirred well with a glass rod and placed in a water bath at $37^{\circ} \mathrm{C}$. for one and one-half hours. The rods were left in the tubes and used for occasional stirring of the mixture. The serum was then separated from the zymin by centrifugation. It was stored undiluted in the frozen state. Before using, the reagent was diluted 1:5 with buffered saline solution. This solution is stable for at least three to four weeks.

Preparation of $R 4$. To inactivate the fourth component of complement, $0.12 \mathrm{ml}$. of $0.15 \mathrm{M}$ hydrazine was added to $1 \mathrm{ml}$. of guinea pig serum, mixed thoroughly and incubated in a water bath at $37^{\circ} \mathrm{C}$. for one hour. It was stored undiluted in the frozen state. Before use it was diluted 1:5 with buffered saline.

Titration of complement components. Whenever a sufficient amount of spinal fluid was available, the quantitative method of Wadsworth et al. (13) was used as in previous studies $(14,15)$. However, in the majority of cases only enough fluid was obtained to enable us to apply a qualitative test as follows: The presence of complete hemolysis of $0.2 \mathrm{ml}$. of a $5 \%$ suspension of sensitized sheep's red blood cells in $0.15 \mathrm{ml}$. of spinal fluid was read as $100 \%$ hemolysis. Partial hemolysis was read by comparison with color standards (13) representing percentages of hemolysis ranging from $5 \%$ to $95 \%$ in intervals of $5 \%$.

Spinal fluid specimens. The spinal fluids used in this study were those collected by the Division of Acute Infectious Diseases of the Central Nervous System of the Bureau of Laboratories of the New York City Department of Health. These specimens were routinely examined for total protein, sugar content, cell count and the presence of micro-organisms, and the results were made available for comparison with titers of complement activity. ${ }^{1}$

1 Acknowledgment is made to Miss Ruth Gosling, Bacteriologist, Bureau of Laboratories, New York City Department of Health, who performed the routine examinations.
A total of 43 specimens were examined from 43 cases of cerebrospinal diseases, including cases of meningitis caused by the pneumococcus, meningococcus, beta hemolytic streptococcus, influenza bacillus, tubercle bacillus, as well as from cases diagnosed as poliomyelitis, measles encephalitis, postvaccinial encephalitis, mumps encephalitis, encephalomyelitis and other diseases as indicated in Tables I and III. All specimens were tested within 72 hours of collection, and the majority were tested within 24 hours of collection. All specimens were kept at refrigerator or freezing temperatures during the interval. From previous observations on blood serum (15), it is unlikely that the delay between collection and testing was a factor in the results obtained.

TABLE II

Median concentration of spinal fluid sugar and protein according to complement components present

\begin{tabular}{l|c|c|c}
\hline $\begin{array}{c}\text { Complements } \\
\text { components } \\
\text { present* }\end{array}$ & $\begin{array}{c}\text { Number } \\
\text { of cases }\end{array}$ & $\begin{array}{c}\text { Median } \\
\text { protein conc. } \\
(\mathrm{mg} . / 100 \mathrm{ml} .)\end{array}$ & $\begin{array}{c}\text { Median } \\
\text { sugar conc. } \\
(\mathrm{mg} . / 100 \mathrm{ml} .)\end{array}$ \\
\hline Large & 7 & 259 & 12 \\
Moderate & 15 & 82 & 29 \\
Small & 17 & 39 & 56 \\
\hline
\end{tabular}

* Large $=$ All four components present (complement activity).

Moderate $=$ Three components present

Small $=$ Two or one components present

It would have been desirable to test for complement components in every specimen of spinal fluid from each patient so as to follow the exact trend of the appearance and disappearance of individual components during the course of disease. This study was limited, however, to individual observations during the disease because of the method of collection of specimens. Nevertheless, the data as collected adequately support the conclusions reached in this paper.

In most instances, spinal punctures were performed by hospital internes and the specimens sent to the Bureau of Laboratories by messenger. The amount of spinal fluid necessary for the performance of routine examinations was removed, and the remainder forwarded for complement titration.

\section{RESULTS AND DISCUSSION}

Table I, consisting of analyses of single specimens from individual cases of meningitis, demonstrates the correlation of the changes in complement activity with those in protein and sugar concentrations. The greater the deviation of the routine laboratory findings from normal, the greater the number and the concentration of the individual components. This is further demonstrated in Table II. Thus complement titrations, 
TABLE III

Results of titration of complement components in cerebrospinal fluids compared with laboratory findings from cases of non-bacterial infections

\begin{tabular}{|c|c|c|c|c|c|c|c|c|c|c|c|c|}
\hline \multirow[b]{2}{*}{$\begin{array}{l}\text { Case } \\
\text { No. }\end{array}$} & \multirow{2}{*}{$\begin{array}{c}\text { Date of } \\
\text { onset of } \\
\text { cerebral } \\
\text { symptoms }\end{array}$} & \multirow{2}{*}{$\begin{array}{c}\text { Date } \\
\text { spinal } \\
\text { fluid was } \\
\text { taken }\end{array}$} & \multirow[b]{2}{*}{ Diagnosis } & \multicolumn{5}{|c|}{ Complement components } & \multicolumn{4}{|c|}{ Laboratory findings* } \\
\hline & & & & $\mathrm{C}^{\prime}$ & $C^{\prime} \mathbf{1}$ & $c^{\prime} 2$ & $c^{\prime} 3$ & $C^{\prime} 4$ & $\begin{array}{c}\text { Total } \\
\text { protein } \\
\text { in mgm. } \\
\text { per } 100 \mathrm{ml} .\end{array}$ & 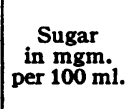 & $\begin{array}{l}\text { Cell } \\
\text { count }\end{array}$ & $\begin{array}{l}\text { Micro- } \\
\text { organisms }\end{array}$ \\
\hline 25 & $2 / 7$ & $2 / 9$ & $\begin{array}{l}\text { Mumps } \\
\text { encephalitis }\end{array}$ & - & $++t+$ & - & - & ++++ & 10 & 59 & ? & Neg. \\
\hline $\begin{array}{l}26 \\
27\end{array}$ & $\begin{array}{l}3 / 1 \\
4 / 25\end{array}$ & $\begin{array}{l}3 / 1 \\
4 / 25\end{array}$ & $\begin{array}{l}\text { Encephalitis } \\
\text { Post-measles }\end{array}$ & $\overline{-}$ & $\begin{array}{l}+++t \\
+++t\end{array}$ & $=$ & $=$ & $\begin{array}{l}++++ \\
+++t\end{array}$ & $\begin{array}{l}20 \\
93\end{array}$ & $\begin{array}{r}58 \\
134\end{array}$ & $\begin{array}{l}\text { Norm. } \\
\text { Sl. I. }\end{array}$ & $\begin{array}{l}\text { Neg. } \\
\text { Neg. }\end{array}$ \\
\hline 28 & $4 / 30$ & $6 / 8$ & $\begin{array}{l}\text { Post-measles } \\
\text { encephalitis }\end{array}$ & - & +++ & - & - & $+++t$ & 26 & 50 & Norm. & Neg. \\
\hline 29 & $6 / 6$ & $6 / 11$ & Post-measles & - & +++ & - & - & +++ & 40 & 55 & Norm. & Neg. \\
\hline 30 & $6 / 12$ & $6 / 18$ & $\begin{array}{r}\text { Post-vaccinial } \\
\text { encephalitis }\end{array}$ & - & +++ & - & \pm & +++ & 40 & 66 & Norm. & Neg. \\
\hline 31 & $5 / 26$ & $6 / 3$ & $\begin{array}{r}\text { Post-vaccinial } \\
\text { encephalitis }\end{array}$ & - & +++ & - & - & $++t+$ & 13 & 37 & Norm. & Neg. \\
\hline $\begin{array}{l}32 \\
33 \\
34\end{array}$ & $\begin{array}{l}\overline{5 / 29} \\
7 / 15\end{array}$ & $\begin{array}{l}6 / 20 \\
6 / 7 \\
7 / 18\end{array}$ & $\begin{array}{l}\text { Poliomyelitis } \\
\text { Poliomyelitis } \\
\text { Encephalo- } \\
\text { myelitis }\end{array}$ & $\overline{-}$ & $\begin{array}{l}++++ \\
+++\end{array}$ & $=$ & $\bar{z}$ & $\begin{array}{c}+++t \\
++t \\
+\end{array}$ & $\begin{array}{l}55 \\
75 \\
40\end{array}$ & $\begin{array}{r}136 \\
85 \\
90\end{array}$ & $\begin{array}{l}\text { Sl. I. } \\
\text { M.I. } \\
\text { M.I. }\end{array}$ & $\begin{array}{l}\text { Neg. } \\
\text { Neg. } \\
\text { Neg. }\end{array}$ \\
\hline $\begin{array}{l}35 \\
36 \\
37 \\
38 \\
39\end{array}$ & $\begin{array}{c}6 / 25 \\
\overline{-} \\
6 / 19 \\
10 / 8\end{array}$ & $\begin{array}{c}7 / 2 \\
7 / 12 \\
4 / 17 \\
6 / 21 \\
10 / 10\end{array}$ & $\begin{array}{l}\text { Encephalitis } \\
\text { Encephalitis } \\
\text { Encephalitis } \\
\text { Encephalitis } \\
\text { Acute en- } \\
\text { cephalitis }\end{array}$ & $\begin{array}{l}\bar{z} \\
\bar{z}\end{array}$ & $\begin{array}{c}++++ \\
+++t \\
++++ \\
++++ \\
\pm\end{array}$ & $\begin{array}{l}= \\
\bar{z} \\
-\end{array}$ & $\begin{array}{l}\bar{z} \\
\bar{z}\end{array}$ & $\begin{array}{c}++++ \\
++++ \\
+++ \\
=\end{array}$ & $\begin{array}{l}89 \\
24 \\
18 \\
25 \\
41\end{array}$ & $\begin{array}{r}58 \\
226 \\
56 \\
95 \\
89\end{array}$ & $\begin{array}{l}\text { M.I. } \\
\text { Norm. } \\
\text { Norm. } \\
\text { Sl. I. } \\
\text { Norm. }\end{array}$ & $\begin{array}{l}\text { Neg. } \\
\text { Neg. } \\
\text { Neg. } \\
\text { Neg. } \\
\text { Neg. }\end{array}$ \\
\hline
\end{tabular}

* See legend on Table I

using this method, can be of assistance in evaluating the status of a case of bacterial meningitis.

In cases of diseases of the central nervous system known not to be due to bacterial infection, the complement components were fewer in number and in lower concentrations than those of bacterial infections of the meninges, as shown in Table III.

All spinal fluids available for this study were taken as a result of clinical indications. Consequently, no information is available regarding spinal fluids in individuals who are not ill. However, four fluids in which no complement components were present showed protein, sugar and cells within normal limits. This cannot be considered a control series.

In the case of bacterial infection, the manner in which the components occur in the spinal fluid is characteristic. The components of largest concentration, $C^{\prime} 1$ and $C^{\prime} 4$, most commonly occur; then the third component, and least frequently $\mathrm{C}^{\prime} 2$, which is in smallest concentration. The greater the number of components present, the higher the titer of the individual components. When all four components were present, the spinal fluid was always positive for whole complement. This depended on the presence of $C^{\prime} 2$, the component in least concentration, and not on the particular bacterial incitant of the disease. This same situation obtains in the case of non-bacterial infections, except that it was not possible to determine the order of $C^{\prime} 3$ and $C^{\prime} 2$, since $C^{\prime} 3$ was present in only one case and $C^{\prime} 2$ was present in none of the cases.

It is of interest that in the bacterial infections, the concentrations of the various components of the cerebrospinal fluid correspond to the relative titers of each found in human blood complement, as reported by Heidelberger and his coworkers (9). $C^{\prime} 4$ was present in greatest concentration, and then $C^{\prime} 1, C^{\prime} 3$ and $C^{\prime} 2$, in that order, $C^{\prime} 2$ being the one which determined overall complement titer. The results of Ecker and his associates (16) are similar except that the component in least concentration was found to be $C^{\prime} 2$ or $C^{\prime} 3$, and according to their results, either of these could be the component which determines overall complement titer. It is therefore likely from these results that the presence of complement components in the 
cerebrospinal fluid, during acute inflammatory diseases, results from leakage of the components across the membrane of the choroid plexus, and not from local production of the individual components; however, proof of this must await simultaneous titrations of specimens of blood and cerebrospinal fluid.

\section{SUMMARY}

1. One or more components of complement were always found in the spinal fluid in infectious cerebrospinal disease.

2. In specimens from patients with infections of the central nervous system, an analysis of the number and concentration of the components correlates with the median values of abnormal concentrations of protein and sugar.

3. In specimens obtained from cases of inflammatory diseases of the central nervous system not due to bacteria, the number and concentration of the components are less than those occurring in the bacterial diseases.

4. In inflammatory diseases of the central nervous system, $C^{\prime} 4$ and $C^{\prime} 1$, the components present in largest concentration, occur most frequently. $C^{\prime} 3$ and $C^{\prime} 2$ follow in order of occurrence and in concentration.

5. $C^{\prime} 2$ is found in least frequency and then only in low titer. It is this component which determines total complement activity of the cerebrospinal fluid, since it is only found when the other three components are present.

\section{ACKNOWLEDGMENT}

The technical assistance of Miss Diana Blitz is gratefully acknowledged.

\section{BIBLIOGRAPHY}

1. Ward, H. K., and Fothergill, L. D., Influenzal meningitis treated with specific antiserum and complement. Am. J. Dis. Child., 1932, 43, 873.

2. Kolmer, J. A., Toyama, I., and Matsunami, T., The influence of active normal serum (complement) upon meningococci. I. The opsonic activity of fresh normal serum alone and in combination with antimeningitis serum for meningococci. J. Immunol., 1918, 3, 155.

3. Bunim, J. J., and Wies, F. A., The use of fresh human serum (complement) in meningococcus meningitis. J. A. M. A., 1933, 100, 178.

4. Fondé, E. C., The use of fresh human serum (complement) in combination with the antiserum in the treatment of meningococcic meningitis. J. A. M. A., 1935, 105, 110.

5. Ward, H. K., and Wright, J., Studies on influenzal meningitis; problems of specific therapy. J. Exper. Med., 1932, 55, 223.

6. Hauptmann, A., Der Weg über den Liquor. Ein neuer Zugang zum Versändnis der Pathogenese toxischer cerebrospinaler Krankungen. Klin. Wchnschr., 1925, 4, 1297.

7. Ciuca, M., L'alexine et les anticorps de la circulation générale, existent-ils dans le liquide céphalorachidien? Compt. rend. Soc. de biol., 1911, 70, 79.

8. Hegedüs, A., and Greiner, H., Quantitative Bestimmung der Komplementbestandteile. Ztschr. f. Immunitätsforsch. u. exper. Therap., 1938, 92, 1.

9. Bier, O. G., Leyton, G., Mayer, M. M., and Heidelberger, M., A comparison of human and guinea pig complements and their component fractions. J. Exper. Med., 1945, 81, 449.

10. Ecker, E. E., Pillemer, L., and Seifter, S., Immunochemical studies on human serum; human complement and its components. J. Immunol., 1943, 47, 181.

11. Pillemer, L., and Ecker, E. E., The terminology of the components of complement. Science, 1941, 94, 437.

12. Ecker, E. E., Pillemer, L., Seifter, S., Dozois, J. F., and San Clemente, C. L., Human complement. Science, 1943, 98, 43.

13. Wadsworth, A., Maltaner, E., and Maltaner, F., Quantitative determination of fixation of complement by immune serum and antigen. J. Immunol., 1931, 21, 313.

14. Rutstein, D. D., and Walker, W. H., Complement activity in pneumonia. J. Clin. Invest., 1942, 21, 347.

15. Pohl, A. W., and Rutstein, D. D., The deterioration of complement activity in normal human serum. J. Clin. Invest., 1944, 23, 177.

16. Ecker, E. E., Seifter, S., and Dozois, T. F., Human complement. J. Lab. \& Clin. Med., 1945, 30, 39. 